Louisiana State University

LSU Digital Commons

Faculty Publications

Department of Oceanography \& Coastal

Sciences

1996

\title{
Hydrologic Restoration of Coastal Wetlands
}

R. Eugene Turner

euturne@lsu.edu

R. R. Lewiss III

Follow this and additional works at: https://digitalcommons.Isu.edu/oceanography_coastal_pubs

\section{Recommended Citation}

Turner, R., \& Lewiss, R. R. (1996). Hydrologic Restoration of Coastal Wetlands., 65-72. Retrieved from

https://digitalcommons.Isu.edu/oceanography_coastal_pubs/146

This Article is brought to you for free and open access by the Department of Oceanography \& Coastal Sciences at LSU Digital Commons. It has been accepted for inclusion in Faculty Publications by an authorized administrator of LSU Digital Commons. For more information, please contact ir@lsu.edu. 
Special Issue: Hydrologic Restoration of Coastal Wetlands Wetlands Ecology and Management vol. 4 no. 2 pp 65-72 (1997) SPB Academic Publishing bv, Amsterdan

\title{
Hydrologic restoration of coastal wetlands
}

\author{
R.E. Turner' ${ }^{1}$ and R.R. Lewis, III $^{2}$ \\ 'Coastal Ecology Institute, Louisiana State University, Baton Rouge, Louisiana 70803, USA: \\ -Lewis Environmental Services, Inc., P.O. Box 20005 Tampa. Florida 33622-0005. USA
}

Keywords: wetland restoration, hydrology, coastal ecosystems, science and management

\begin{abstract}
Hydrologic modification of coastal wetlands is pervasive, continuing and longstanding in the US. Appreciation for the subtleties of the direct and indirect effects of hydrologic changes on emergent vegetation, soils and co-dependent flora and fauna is contributing to restoration efforts. However the results of wetland restoration/rehabilitation are mostly empirical, rather than scientific in understanding. Science is contributing to the management interest by providing documentation of the past and present failures and successes, and, unveiling the fundamental understanding necessary to move from one wetland to another in an informed and adaptable manner. The papers in this volume are introduced within this framework.
\end{abstract}

\section{Introduction}

The hydrology of coastal tidal wetlands has been directly changed as wetlands have been surrounded by levees, diked, impounded, ditched and dredged, and also indirectly changed from hydrologic alterations in the watersheds and inappropriate development. The consequential changes in wetland flooding and drying cycle (e.g., water depth, flood duration and frequency) affect both belowground and aboveground water quality, flora, and fauna in ways that are sometimes obvious (e.g., acid sulfate soil formation, emergent plant conversion to open water, sedimentation or erosion) and at other times subtle. Restoring or rehabilitating wetland hydrology is the focus of the papers in this special issue of Wetlands Ecology and Management. This focus has a decidedly applied and empirical aspect because of the inexperience of management in these endeavors, the societal interests, and the dearth of systematic investigations and, especially, of comparative studies.

\section{Examples of early hydrologic changes}

There is long-standing recognition that coastal wetland soils could be changed with human intervention, which was primarily for agricultural benefit. During the beginning of this century, many impoundments were build on the east coast of the United States and in Louisiana to reclaim marsh for agriculture. Smith (1907), Warren (1911), and Okey $(1918 \mathrm{a}, \mathrm{b})$ described these projects. Two significant processes occurred simultaneously following impoundment: soil shrinkage and vegetation changes. Smith reported,

"Where the marshes have been embanked and improved they have shrunk considerably. Instances have been noted where this shrinkage of settlement amounts to three feet" (Report of the State Geologist of New Jersey, 1895; cited in Smith 1907, p. 5).

and

"As the salt water drains out of the turf layer and fresh water takes its place, disintegration of the root mass begins. If the soil is turned or plowed or otherwise cultivated this process is 


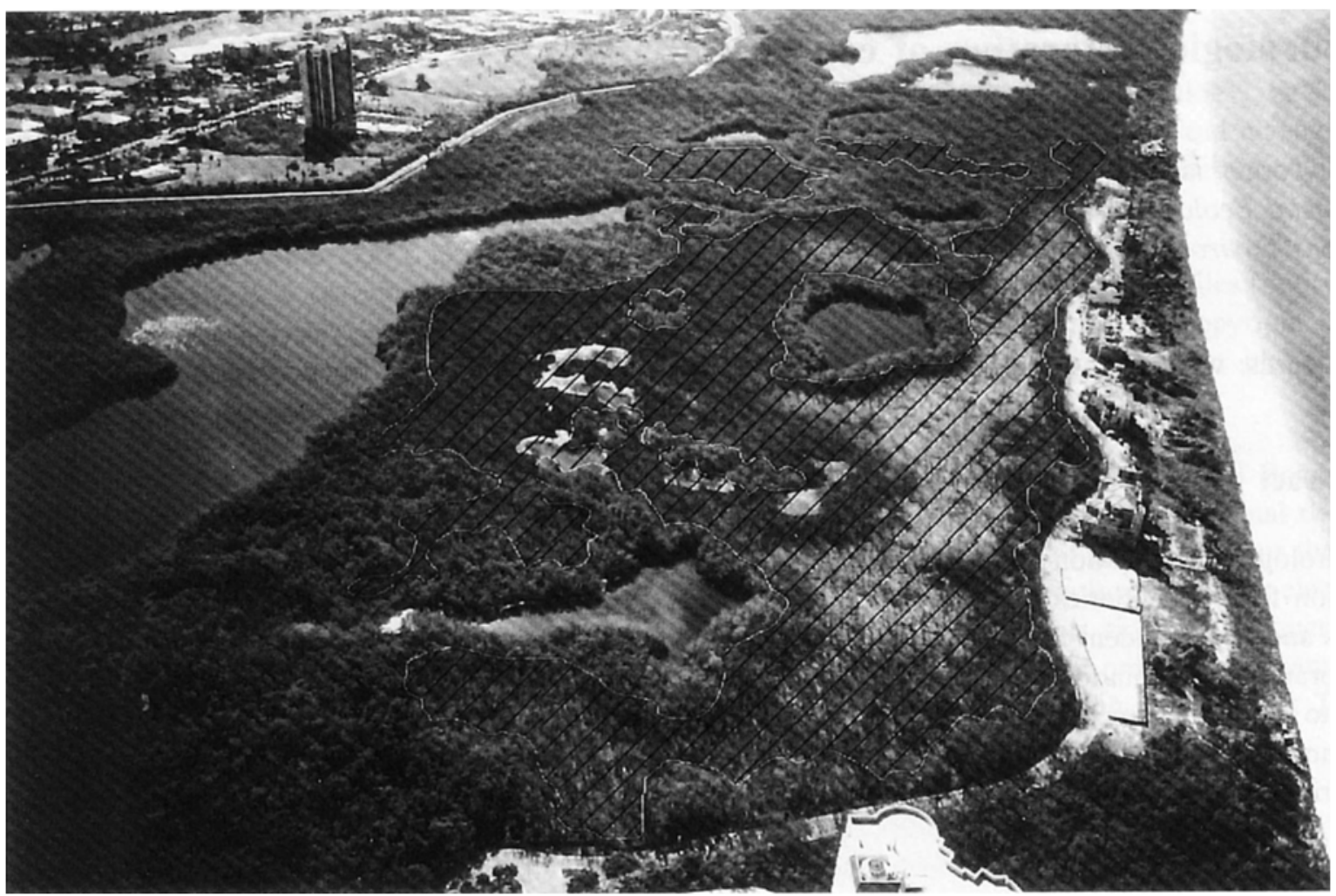

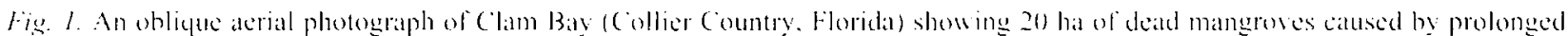

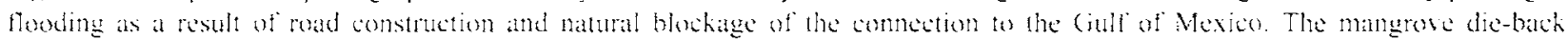
zonc is outlined. Upper Clam Bay is the water body in the upper left hand quadrat of the photograph. (December 1945 : photo. graph by R.R. Lewis. III).

increased in rapidity. and what was a high spongy turf becomes a thin layer of very rich vegetable mold. Six inches of turf will reduce to one inch of soil, as the water drains out of the lower layers the soil becomes more compact" (Smith 1907, p. 17).

and

"Forty years ago the Elizabeth marshes, containing about 2.200 acres. were quite generally cut over and good crops of hay were obtained. There was considerable ditching done. but it was not kept up and as the marsh was crossed and cut up by the railroads without regard to the dranage system, matters became gradually worse: the meadow rotted, the black and salt grass was replaced by sedges and other useless stuff, and less and less was cut each year until, for a decade past. little or nothing has been cut from the area west of the central railroad" (Smith 1907. p. 13).

In Louisiana. marsh shrinkage following impoundment of coastal wetlands (formed 70 years ago) amounted to $3 \mathrm{~cm}$ annually (Tumer and Neill. 1984), or about 40 times the present rate of sealevel rise. These impounded marshes have mostly remained as open water following abandonment of the agricultural enterprises (Turner and Neill. 1984). Soil chemistry changed and subsidence increased following the tidal restrictions in a California salt marsh. This was accompanied by altered plant distributions (Eilers 1980). Jimenez 't al. (1985) list changes in hydrology as one of the six main causes of mortality in mangrove forests. Seven of 27 examples discussed $(27 \%)$ are attributable to changes in hydrology. 


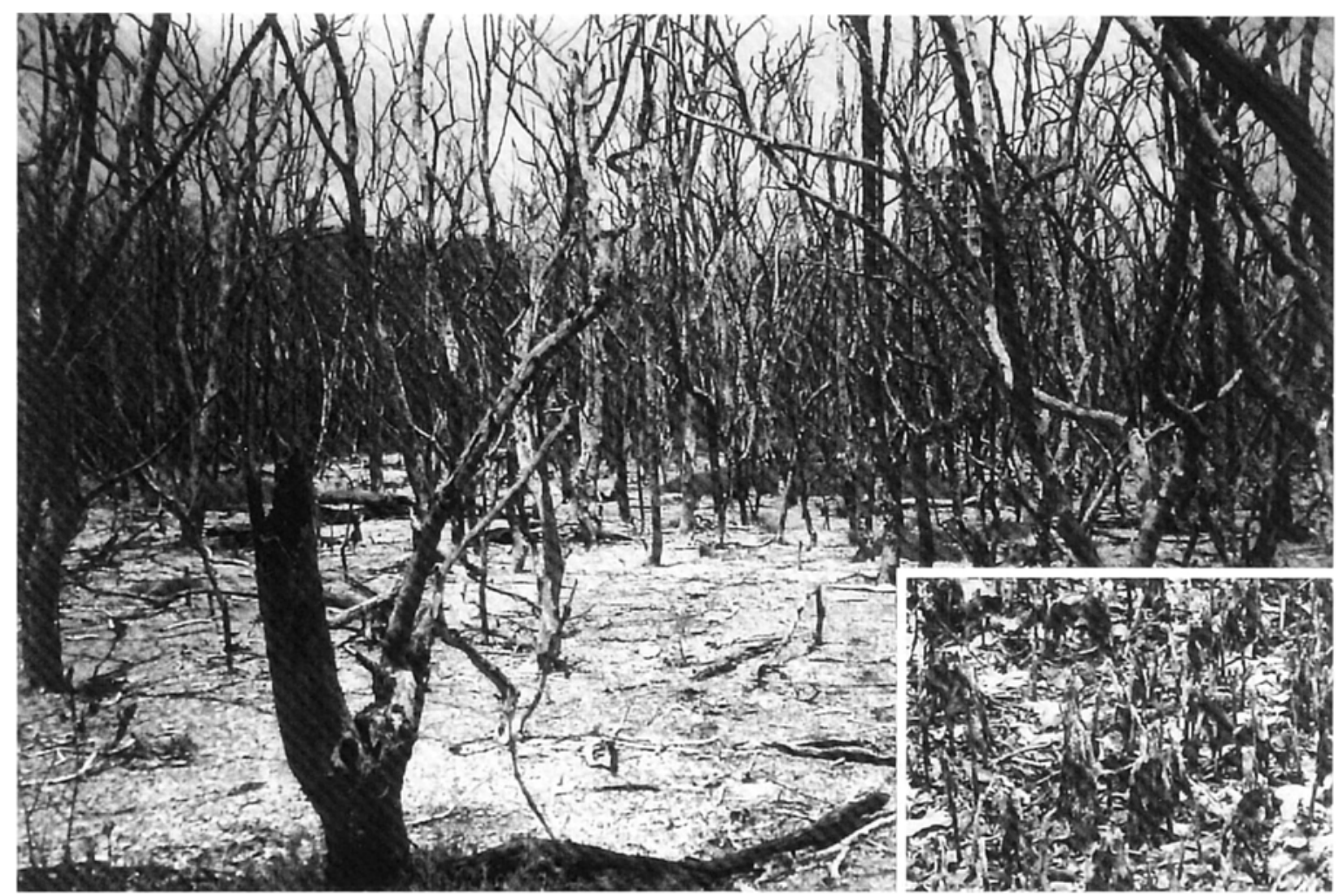

Fig. 2. A ground level iew (April 1990) of the dead mangroves shown in Fig. I before hydrologic restoration. The insert shows algal mats draped on mangrose pneumatophore an indication of prolonged tlooding (photographs by R.R. Lewis. III).

\section{Recent cause-and-effect examples}

The cause-and-effect consequence of the hydrologic changes on coastal wetland loss is becoming more apparent and with increasing frequency. Some examples are shown Figs $1-4$ and others discussed in the papers in this volume. The hydrology of a mangrove system in Clam Bay (Collier Country. Florida) was changed when a road was built across a natural channel leading to the Gulf of Mexico. Trees were killed over a 20 ha area (Figs. 1 and 2). Note that the shape of the dicback zones are characteristically located behind an apparently healthy narrow band of mangroves next to the main water body (Upper Clam Bay) or next to internal tidal ponds. Detailed survey information has shown that the fringe mangroves are located on a slightly higher $(+0.1 \mathrm{~m})$ ridge of mangrove peat that accumulated over the last 40 years since the northern tidal connection to the Gulf of Mexi- co was blocked. The dead mangroves (Figure 2) are largely black mangroves (fricennia germinans) located in a slightly depressed basins. These accumulate excess rainwater and adjacent runoff that cannot drain off due to closure of historical tidal channels as tidal velocities have been reduced and mangroves have overgrown and blocked the channels. Successful restoration is currently being completed by reopening these historic tidal channels.

Live mangrove cover declined from 51.150 ha in 1956 to 30.690 ha in 1992 (Twilley, pers. comm.) in Cienaga Grande de Santa Marta, Columbia. The cause of these changes appears to be due to hydrologic modifications from a road that reduced freshwater fluxes into the area and produced hypersaline conditions lethal to mangroves (Fig. 3). Lewis (1990a) reports several similar examples from the island of Vieques off the coast of Puerto Rico. Zucca (1982) observed 


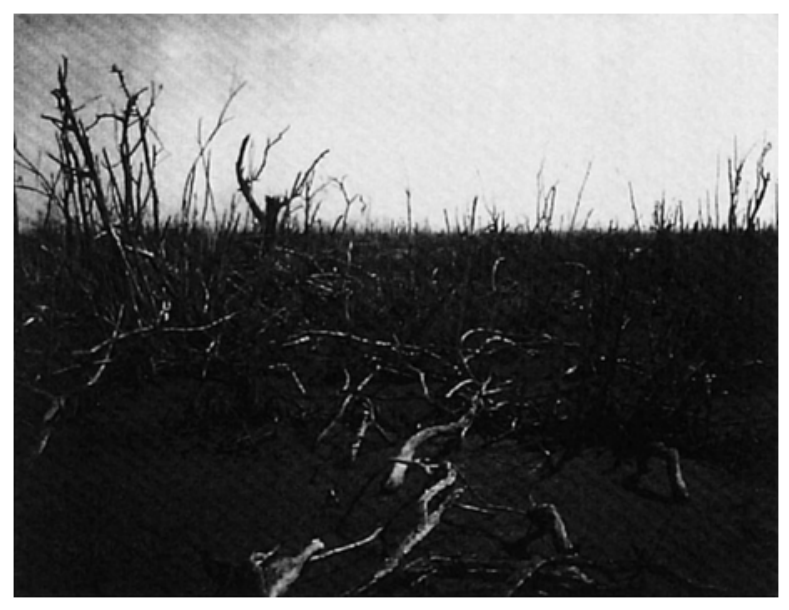

Fig. 3. Ground level view of dead mangroves in the Cienaga Grande (Columbia) estuary. (December 1995; photograph by R.R. Lewis. III).

a similar response in Puerto Rico when a road was built from higher ground through a mangrove forest and towards the sea. Another, different, example is in Fig. 4 from south Louisiana, where $40 \%$ of the US coastal wetlands are. Much of the nearby marsh (near Jug Lake) turned to open water when a canal was built to facilitate boat traffic. Note that the marsh on eastern side is mostly still marsh. The 60 year history of canal dredging and wetland loss in coastal Louisiana shows strong empirical evidence of the indirect relationships (mostly detrimental to the wetland area) between hydrology and habitat (Fig. 5; Bass and Turner 1997, Turner 1997). The changes may be somewhat unpredictable in time and space, but it is an indisputable observation that they occur. These are examples, then, of how a strictly engineered solution to a transportation problem may have unintended consequences to the natural system.

\section{Hydrologic restoration and rehabilitation}

The present interest in wetland restoration has been supported by these early experiences, a diminished resource with more intense actual and proposed uses, as well as changing societal management resources, information, experience and value for wetlands (e.g., Kusler and Kentula 1982, Mitsch and Gosselink 1993, Zedler et al. 1996).
There is often an understandable 'do something' sense of urgency to these efforts. These interests are also broader than just restoring wetlands, as evidenced in the new journals, books and professional newsletters of the past decade with the word 'restoration' in their title. One value of science is to clearly and dispassionately document and critically evaluate (as quantitatively as possible) both the social experiment and the ecosystem response in such a way as to contribute to the present and future management issues for that particular wetland and for all other wetlands.

Reversal of these hydrologic changes, whether it be called hydrologic restoration or rehabilitation, has often been successful. Fig. 6 shows an example for one project at the Laguna Boca Quebrada, Vieques, Puerto Rico (Lewis 1990a, 1990b). More than one hundred ha of dead mangroves were killed when the hydrology was altered. Vegetation came back when the hydrologic change was reversed by removing a filled roadway across the historic tidal connection to the ocean. Harrington and Harrington (1982) documented a particularly dramatic example of re-vegetation following hydrologic restoration for a Florida mosquito impoundment. Stearns et al. (1940) documented the changes in the water table and ground level following construction of mosquito ditches in the Cleaver Wetland, Delaware. They conducted what might have been the first wetland restoration project in the US, when they filled in these ditches in 1938, after landowner complaints about lost muskrat harvest. When the hydrology was reestablished, the direction of the changes in water table and ground level reversed (Fig. 7). Trepagnier et al. (1995) showed how the natural disintegration of impoundment levees was leading to a reversal of emergent macrophyte to open water conversions in south Louisiana (USA). The revegetation rate was dependent on factors related to the wetland hydrology, e.g., water body size and relative dimension and loss of the dredged levees surrounding these wetlands. Roman et al. (1984) documented a wetland restoration in Connecticut marsh. After the tidal restriction was removed the plants responded within a few years. Simenstad and Thom (1996) documented a similar successful, or partially-successful, wetland restoration project on the west coast (USA). 


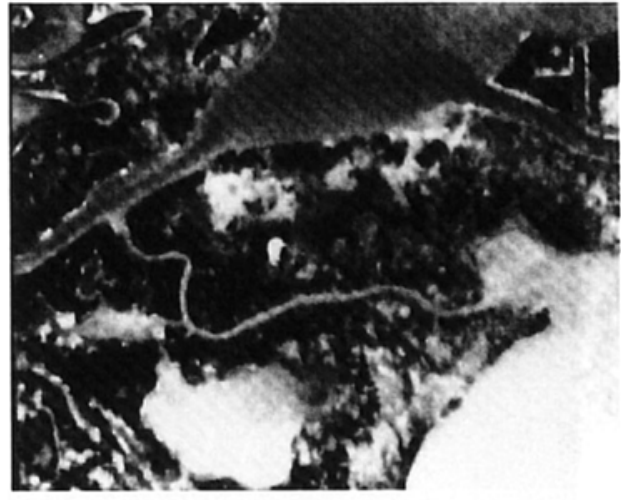

1952

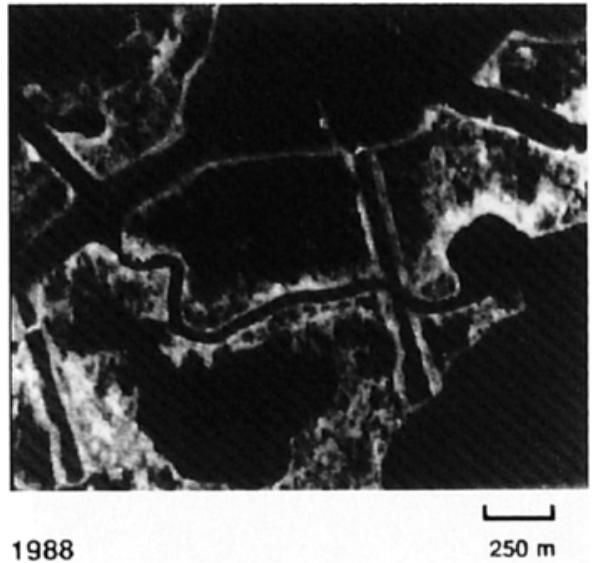

1988

Fig. A. A marsh (center of the photograph) near Jug Lake. Terrebonne Parish, in coastal Louisiana (USA). The wetland was traversed by a canal around 1971. Within 2 years afterwards the open water area changed from 15 to $80 \%$ (adapted from Turner $2 t$ al. 1994).

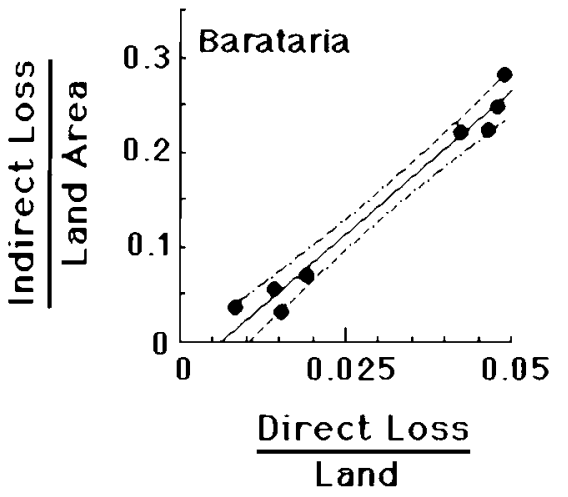

Fig. 5. The relationship between the indirect and direct land losses from the 1930 s to 1990 expressed as a percentage of the original land area for the Barataria Basin. south Louisiana (USA). Each dot represents the changes from land to water within a $15^{\prime}$ quadrangle map. Land loss is almost all (>97\%) wetland habitat conversion to open water. Direct land loss is due to dredging channels in wetlands. The linear regression is shown with a $95 \%$ Confidence Interval for the $Y$ intercept (from Turner, 1997).

\section{These papers}

Haltimer et al. (1996) point out that wetland mitigation in California began with a simple brute force restoration "fix" that was sometimes successful, but that it is now developing some sophistication to improve success rates. What might seem a simple remedy, removing a tidal barrier, for example, may cause an unexpected surprise, e.g., shoreline erosion, channel migration or unexpected species invasion. Developing successful ecosystem management involves acknowledging the uncertainty and doubt about how best to proceed and what to expect. The report of the Ecological Society of America Committee on the Scientific Basis for Ecosystem Management (Christensen et al. 1996) points out that because we do not know the best answers, indeed, sometimes the questions, that the evolution of the relationships between science and management will be adaptive. The eminent ecosystem ecologist Holling (1996) wrote that "it is an open question whether ecosystem management will become a passing fad, an expansion of existing rigid bureaucratic procedures, or a sustaining foundation for learning to deal with interactions between people, nature, and economic activities." We certainly hope it the results will be more like the last of his three choices. To contribute to that ongoing process is one goal of the papers in this volume.

Haltimer et al (1996) describe the complexities in trying to support two endangered bird species (light-footed clapper rail and California least tern) and one endangered plant (salt marsh bird's-beak) through two mitigation projects in southern California. The 'performance criteria' of managers was partially successful in restoring fish habitat (as measured by regulatory standards), but not for birds. Primary deficiencies in the created/restored habitat were related to hydrologic parameters, in- 


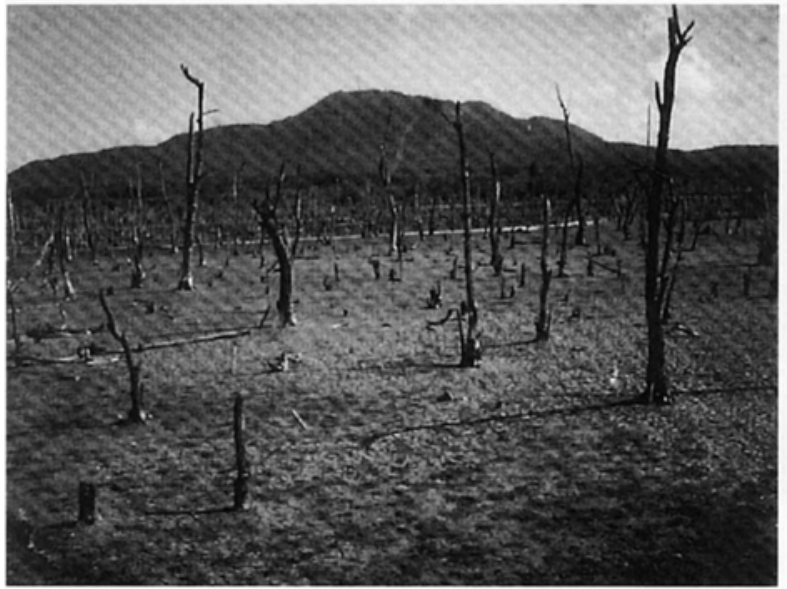

A

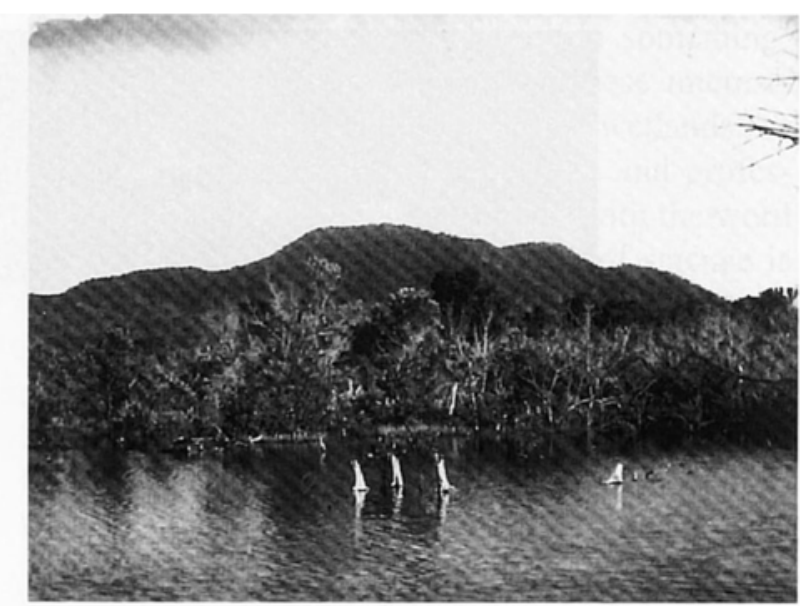

B

Fig. 6. A. One hundred ha of dead mangroves at the Laguna Boca Quebrada estuary. Vieques. Puerto Rico. in December 1985. B. Same as A. after hydrologic restoration. April lygl (photographs by R.R. Lewis. III).

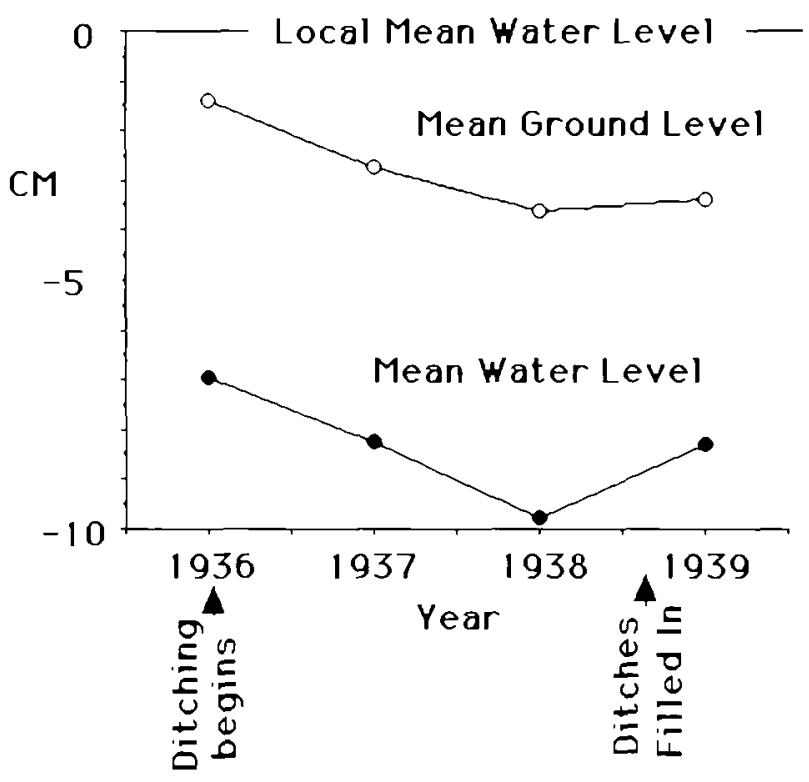

lig. F. Changes in the water table and ground lesel following construction of mosyuto ditches in the Cleaver Wetland studied by Steams al al. (194(0). When the ditches were filled in 1938. the changes in water table and ground level reversed direction

cluding salinity and flooding patterns as well as the interactions between site topography and channel functions.

Brockmeyer et al. (1996) review the effects of impounding the Indian River Lagoon, Florida (USA) salt marshes to control mosquitoes, and the attempts to reverse the significant environmental impacts on plants, fish and invertebrates. Rapid recovery following hydrologic restoration is indicated and is expected to reach 9.454 ha by the end of 1998 , representing $60 \%$ of the impounded wetlands in the entire IRL system. One stumbling block is private ownership of many of the remaining isolated impoundments.

Weinstein et al. (1996) discuss a Delaware Bay salt marsh restoration program on a former salt marsh hay farm. The project is primarily designed with fisheries species in mind. as part of an oftsite compensatory mitigation program for fish loss due to power plant operations. The projected restoration trajectory and equilibrium size was determined, in part, on natural nearby reference sites and former salt marsh farms that deteriorated as a result of stom damage. A method for combining many individual parameters (e.g., nekton, fish, detritus) into a single success index is also presented along with adaptive management thresholds and corrective measures to used to guide the restoration process.

Burdick and Dionne (1996) describe two tidal flow restoration projects in New England (USA). One project involved complete hydrologic restoration and the other a partial restoration. Compared to the nearby reference sites, water levels, soil salinities and fish use responded positively to restoration, and plant communities had shifted in the 
direction of the original plant community equilibrium position. Partial hydrological restoration was only partially successful in meeting the project goals, but would scemingly be completely successful if the hydrology were completely reversed.

The favorable ecological response to these restoration efforts and others has taken a decade or less and provides reason for optimism in restoration efforts. These empirical results are based on successful projects. Many other projects were not pursued, which is also a sign of success if skilled advice was heeded and the more favorable ones chosen. It is the accumulated knowledge. experience and skills of scientists and managers working together from their different strengths that will favor more projects with greater success in the future, and justify society's confidence in meeting our common goal to restore wetlands.

\section{Acknowledgments}

We thank the authors of the papers in this volume for their presenting their work. The preparation for this article was supported by a US EPA grant through the Gulf of Mexico Program.

\section{References}

Bass. A. and Tumer, R.l: 1997. Relationships between salt marsh loss and dredged camals in three south Louisiana estuaries. J. Coastal Research, 13: (in press).

Brockmeyer. R.t... jr.. Rey. J.R., Vimstein. R.W.. Gilmure, R.G. and Farnest. I. 1900. Rehabilitation of impounded estuarine wetlands by hydrologic reconnection to the Indian River Lagoon. Florida. Watlands Ecology and Management, this issue.

Burdick. D.M. Dionne, M.. Boumans, R.M. and Short, F.T. 1996. Contrasts in ecological responses to tidal restoration of two New England salt marshes. Wetlands Leology and Management, this issue

Christensen. N.L. Bartuska, A.M. Brown. J.1H.. Carpenter, S., D'Antonia, C.. Francis. R.. Franklin. J.F.. MacMahon, J.A.. Noss, R.F., Parsons. D.J.. Peterson. C.H.. Turner, M.G. and Woodmansec. R.G. logh. The report of the Ecological Society of Anerica committe on the Scientitic Basis for Ecosystem Management. Ecol. Applications. 6: 665-69)1

Eilcrs. H.P. 1980. Ecology of a coastal salt marsh after longterm absence of tidal fluctuation. Bull. Southem California Acad. Sci., 79: 55-64.

Haltiner. J.. Zedler. I.B.. Boyer. K.E.. Willians, G.D. and
Callaway. 1. 1090. Influence of physical processes on the design, functioning and evolution of restored tidal wetlands in Califomia. Welands Ecology and Management, this isstle.

Harringtom. R.W. Jr.. and Harrington. I:S. 1982. Effects on fishes and their forage organisms of impounding a Florida salt marsh to prewent breeding by salt marsh mosquitos. Bull. Mar. Sci. 32: $523-531$.

Holling. ('S. 1000. Surprise for science, resilience for ecosystems and incentives for poople. Ecol. Applications, 6: 733736.

Jimence. J.A. Lugo, A.E. and (eintron. G. 1985. Tree mortality in mangrose forests. Biotropica. 17: 177-185.

Kusler, I.A. and Kentula. M.t. (eds.) lo90. Hetland Creation and Restoration: The Status of the Science. Lstand Press. Washington. D.C. 59+ pp.

I.ewis. R.R. 1990a. Managoment and restoration of mangrose forests in Puerto Rico, the US. Virgin lslands, and Florida. U.S.A. In: Memorias. Ecologia y Conservacion del Delta de Los Rios Usamacinta y Grijalsa. Pp. 319-342. listado de Tabasco. Mexico.

Lewis, R.R. 1990b. Creation and restoration of coastal wellands in Puerto Rico and the U.S. Virgin Islands. In: Kusler. J.A and kentula. M.E. (eds.) Weland (reation and Restoration. The Status of the Science. pp. 103-123. Island Press. Washinglon. D.C. xxy $+595 \mathrm{pp}$.

Mitsch. W.I. and J.G. Gosselink. 1093. Wetlands. Van Nostrand Reinhold. New Jork, Ny'.

Okey. (.W. 19) kit. The subsidenee of muck and peat soils in southern Louisianal and Florida. Am. Soc. Civil kng.. 82 $396-422$.

Okey. C.W. 1918b. The wet lands of southern Louisiana and lheir drainage. USDA Bull. 652. Prof. Pap. $67 \mathrm{mp}$.

Roman. C.T. Niering. W.A. and Warren. R.S. 1984. Sall marsh regetation change in response to tidal restrictions. laniron. Mgmt. $8: 1+1-1+9$.

Simenstad, C.A. and Thom, R.M. 1996. Fumctional equilafency trajectories of the restored Gog-Le-Hi-Te estuarine wetland. Ecol. Applications, 6: $38-56$.

Smith. I. B. 1907. The New Jersey salt marsh and its improvement. N. I. Agric. Lxp. Stn. Bull., 207: 1-24.

Stcarns, L.A. Mac Creiry, D. and Diligh, F.C. 1940. Effect of ditching for mosquito control on the muskral population of a Delawalre tidewater marsh. University of Delaware Agriculture Fxperiment Station Bulletin No. 225.

Trepagnier. C.M. Kogals. M.A., and Turner. R.l. I995. Evaluation of wetland gain and loss of abandoned agricultural impoundmonts in South Louisiana from 1978 to lose. Restoration Ecology. 34: 294-3013.

Tumer. R.F. and Neill. C. 1984. Revisiting impounded wetlands after 70 years. In: R. J. Varnell (ed.). Water Quality and Wetland Management Conference Procedings. New Orleans. LA., August t-5. 1983. pp. 309-322. (sponsors: Louisiana linvironmental Professionals Association).

Tumer, R.F. 1997. Wetland loss in the northern Gult of Mexico: Multiple working hypotheses. Estuaries. 20 (1): (in press) 
Warren. G.M. 1911. Tidal marshes and their reclamation. U.S. Dept. Agric. Exp. Stn. Bull. 240.99 pp.

Weinstein, M.P., Balletto. J.H. Teal, J.M. and Ludwig. D.F. 1996. Success criteria and adaptive management for a large-scale wetland restoration project. Wetlands Ecology and Management. this issue.
Zedler, J.B., Principal Author. 1996. Tidal Wetland Restoration: A Scientific Perspective and Southern California Focus. California Sea Grant College System. University of California, La Jolla, California Report No. T-038.

Zucca. C.P. 1982. The effects of road construction on a mangrove ecosystem. Trop. Ecol.. 23: 105-123. 